\title{
PENGARUH KURS, GROSS DOMESTIC PRODUCT DAN SOLVABILITAS TERHADAP RETURN SAHAM INVESTOR PADA PERUSAHAAN PERTAMBANGAN
}

\author{
Martina Carissa Dewi ${ }^{1}$ \\ Luh Gede Sri Artini ${ }^{2}$ \\ ${ }^{1,2}$ Fakultas Ekonomi dan Bisnis Universitas Udayana (Unud), Bali, Indonesia \\ email: martinacarissa16@gmail.com
}

\begin{abstract}
ABSTRAK
Investor memperoleh tingkat return yang dipengaruhi oleh faktor mikro ekonomi dan makro ekonomi. Tujuan dari penelitian ini adalah untuk mendapatkan bukti empiris mengenai pengaruh kurs, Gross Domestic Product dan solvabilitas terhadapt return saham. Penelitian ini dilakukan pada perusahaan pertambangan sub sektor batu bara di Bursa Efek Indonesia. Populasi yang digunakan meliputi seluruh perusahaan pertambangan sub sektor batu bara yang terdaftar di BEI periode 2014-2017. Menggunakan teknik sampling jenuh sebagai metode penentuan sampel. Penelitian ini menggunakan analisis data berupa uji regresi linear berganda. Berdasarkan hasil analisis penelitian ditemukan bahwa kurs dan GDP berpengaruh negatif dan signifikan terhadap return saham. Pada solvabilitas yang diproksikan dengan DER berpengaruh positif dan signifikan terhadap return saham.
\end{abstract}

Kata kunci : kurs, Gross Domestic Product, solvabilitas, return

\section{ABSTRACT}

The level of return obtained by investors is influenced by microeconomic and macroeconomic factors. This study aims to obtain empirical evidence regarding the effect of exchange rates, Gross Domestic Product and solvency on stock returns. This research was conducted at the mining company in the coal sub-sector on the Indonesia Stock Exchange. All the coal mining sub-sector companies listed on the Stock Exchange for the period 2014-2017 used as the population. The method of determining the sample used is using a saturated sampling technique. Multiple linear regression test used as the data analysis on this research. Based on the results of the analysis of this study it was found that the exchange rate and GDP had a negative and significant effect on stock returns. The solvency proxied by DER has a positive and significant effect on stock returns.

Keywords: Exchange Rate, Gross Domestic Product, Solvability and Return. 


\section{PENDAHULUAN}

Setiap investasi baik jangka panjang maupun jangka pendek mempunyai tujuan utama untuk mendapatkan keuntungan yang disebut return. Return saham adalah tingkat keuntungan yang dinikmati oleh pemodal atas suatu investasi yang dilakukannya.

Menurut Tandellin (2010:105) return saham merupakan salah satu faktor yang memotivasi investor berinvestasi dan juga merupakan imbalan atas keberanian investor menanggung resiko atas berinvestasi yang dilakukannya.

Terdapat dua jenis return yaitu return realisasi yang merupakan return yang terjadi atau disebut juga sebagai return sesungguhnya dan return ekspektasi yang merupakan return yang diharapkan oleh investor. Return saham menentukan investor mendapatkan capital gain maupun capital loss yang dihitung melalui perhitungan selisih harga saham sekarang dengan harga saham sebelumnya.

Nilai sekarang (present value) dari hasil yang akan diterima oleh investor di masa depan disebut dengan harga saham. Pihak emiten yang dapat menghasilkan harga saham yang bernilai tinggi dapat meningkatkan tingkat return saham oleh investor. Harga saham mengalami fluktuasi dari waktu ke waktu yang mengakibatkan adanya ketidakpastian return saham yang diperoleh investor di pasar modal.

Pasar modal yang umumnya dijadikan media jual beli saham di Indonesia adalah Bursa Efek Indonesa (BEI). Investor dapat bebas memilih untuk menanamkan modalnya di berbagai perusahaan yang terdaftar di BEI tersebut, baik perusahaan jasa atau manufaktur.

Perusahaan jasa dan manufaktur itu sendiri juga dipecah menjadi sektorsektor sesuai dengan bidang-bidangnya. Sektor di BEI yang menjanjikan untuk investasi adalah perusahaan pertambangan sub sektor batu bara (coal mining).

Indonesia menempati urutan kedua penyumbang produksi batubara dunia setelah Australia dengan produksi kurang lebih 190 Juta ton dan diikuti oleh negaranegara lain seperti: India, Afrika, Colombia dan Amerika.

Indonesia memiliki cadangan batubara sebanyak 0,6 persen dari cadangan batubara dunia, atau sekitar 5,229 miliar ton dari total 860 miliar ton di tahun 2014 (Arif, 2014:54). Indonesia mengekspor batu bara ke berbagai negara di dunia yaitu China, Jepang, Korea, dan India.

Melimpahnya cadangan batu bara dalam negeri serta adanya ekspor batu bara ke berbagai negara di dunia, tidak menunjang performa saham batu bara di pasar modal. Sejak tahun 2014 sektor batu bara menunjukkan penurunan harga-harga saham yang berdampak kepada return saham yang juga terus menurun.

Tercatat sejak awal tahun 2014, return saham pertambangan sub sektor batu bara mengalami penurunan yang cukup signifikan yaitu 11 dari 17 emiten memiliki return saham negatif. Penurunan yang cukup signifikan tersebut juga imbas dari fenomena overheating ekonomi China di tahun 2014 yang membatasi impor batu bara ke negaranya.

Laporan Perekonomian Indonesia (LPI) 2014 menyebutkan bahwa: (1) tahun 2014 pertumbuhan ekonomi China lebih rendah dibandingkan tahun 2013, (2) adanya kebijakan pemerintah China untuk mengurangi penggunaan batubara dari total komposisi energi yang digunakan, (3) terjadinya perlambatan ekonomi global, 
khususnya emerging market, (4) pasokan komoditas termasuk batubara yang melimpah secara global .

Tabel 1.

Return Saham Pertambangan Sub Sektor Batu Bara Tahun 2014-2017

\begin{tabular}{llrrrr}
\hline \multirow{2}{*}{ No. Nama Perusahaan } & & \multicolumn{4}{c}{ Return Saham (\%) } \\
\cline { 3 - 6 } & & $\mathbf{2 0 1 4}$ & $\mathbf{2 0 1 5}$ & $\mathbf{2 0 1 6}$ & $\mathbf{2 0 1 7}$ \\
\hline 1 & PT. Adaro Energy Tbk. (ADRO) & $-0,05$ & $-0,50$ & 2,29 & 0,10 \\
2 & PT. Atlas Resources Tbk (ARII) & $-0,47$ & $-0,11$ & 0,30 & 0,88 \\
3 & PT. Baramulti Suksessarana Tbk. (BSSR) & $-0,18$ & $-0,30$ & 0,27 & 0,49 \\
4 & PT. Bumi Resources Tbk. (BUMI) & $-0,73$ & $-0,38$ & 4,56 & $-0,03$ \\
5 & PT. Bayan Resources Tbk. (BYAN) & $-0,22$ & 0,18 & $-0,24$ & 0,77 \\
6 & PT. Darma Henwa Tbk. (DEWA) & 0,00 & 0,00 & 0,00 & 0,00 \\
7 & PT. Delta Dunia Makmur Tbk. (DOID) & 1,10 & $-0,72$ & 8,44 & 0,40 \\
8 & PT. Golden Energy Mines Tbk.(GEMS) & $-0,08$ & $-0,30$ & 0,93 & 0,02 \\
9 & PT. Harum Energy Tbk. (HRUM) & $-0,40$ & $-0,59$ & 2,17 & $-0,04$ \\
10 & PT. Indo Tambangraya Megah Tbk. (ITMG) & $-0,46$ & $-0,63$ & 1,95 & 0,23 \\
11 & PT. Resource Alam Indonesia Tbk. (KKGI) & $-0,39$ & $-0,67$ & 2,57 & 0,08 \\
12 & PT. Samindo Resources Tbk. (MYOH) & $-0,07$ & 0,15 & 0,20 & 0,11 \\
13 & PT. Perdana Karya Perkasa Tbk. (PKPK) & 0,02 & $-0,43$ & 0,00 & 0,34 \\
14 & PT. Bukit Asam Tbk. (PTBA) & 0,23 & $-0,64$ & 1,76 & $-0,02$ \\
15 & PT. Petrosea Tbk. (PTRO) & $-0,20$ & $-0,69$ & 1,48 & 1,31 \\
16 & PT. Golden Eagle Energy Tbk. (SMMT) & 0,06 & $-0,90$ & $-0,13$ & $-0,11$ \\
17 & PT. Toba Bara Sejahtra Tbk. (TOBA) & 0,24 & $-0,27$ & 0,63 & 0,88 \\
\hline Sumber : Data Diolah, 2018.
\end{tabular}

Kondisi-kondisi tersebut menyebabkan permintaan terhadap komoditas batu bara secara global menurun, akibatnya pertumbuhan kinerja saham sektor pertambangan di awal tahun 2014 kurang dari satu persen hingga akhir tahun.

Pada tahun 2015 sektor pertambangan dinilai belum mampu memperbaiki kinerjanya karena di tahun 2015 bertambah dua emiten dari 11 menjadi 14 emiten yang memiliki return negatif dari total 17 emiten. Tahun 2016 performa saham batu bara sudah mengalami peningkatan jumlah emiten batu bara yang memiliki return positif, begitu juga dengan return di tahun 2017 yang sudah meningkat walau ada beberapa emiten yang mengalami penurunan return.

Terdapat fakta bahwa return yang akan diperoleh investor tidak memiliki sebuah kepastian, oleh karena itu investor harus mengumpulkan berbagai informasi terkait return saham yang diperlukan sebelum mengambil sebuah keputusan investasi. Investor memerlukan analisis keuangan untuk membuat keputusan investasinya yaitu dengan menggunakan analisis teknikal dan analisis fundamental. Analisis fundamental dilakukan dengan melakukan analisis ekonomi, industri dan perusahaan.

Penelitian ini menggunakan variabel-variabel yang berasal dari analisis ekonomi yaitu kurs dan Gross Domestic Product (GDP) dan analisis perusahaan 
yaitu solvabilitas. Kurs adalah tingkat dari nilai uang domestik yang dikonvesikan ke nilai mata uang asing (Bodie et al., 2014:175).

Kurs merupakan catatan harga pasar mata uang asing ke dalam mata uang domestik begitu pula sebaliknya. Pemerintah Indonesia berperan penting dalam menentukan kurs agar tercapai situasi yang kondusif di dalam dunia usaha. Kurs dianggap perlu sebagai variabel penelitian ini karena perusahaan batu bara melakukan aktifitas ekspor ke berbagai negara di dunia seperti China, Jepang, Korea dan India, akibatnya setiap transaksi yang dilakukan memiliki keterkaitan dengan kurs Rupiah terhadap Dolar.

Terapresiasi dan terdepresiasinya Rupiah terhadap Dolar akan mempengaruhi kuantitas ekspor batu bara. Meningkat dan menurunnya kuantitas ekspor batu bara akan mempengaruhi harga dan return saham batu bara.

Gross Domestic Product (GDP) merupakan total dari ukuran produksi barang dan jasa di suatu negara (Tandellin, 2010:342). GDP adalah jumlah nilai produk oleh unit-unit produksi pada lingkup wilayah sebuah negara selama satu tahun dan biasanya digunakan sebagai ukuran kesejahteraan ekonomi suatu negara.

GDP mencakup semua hal yang diproduksi oleh perekonomian dan yang dijual secara legal di pasar. GDP dianggap perlu diteliti hubungannya terhadap return saham akibat GDP memiliki komponen yang lengkap yaitu konsumsi, investasi, pembelian pemerintah dan net ekspor. Seluruh komponen tersebut mampu merangkum laju pertumbuhan ekonomi suatu negara, sehingga GDP dipandang mampu menjadi tolak ukur untuk menunjukkan purchasing power suatu negara terhadap batu bara. Meningkat dan menurunnya purchasing power suatu negara akan mempengaruhi permintaan akan batu bara yang akan berimbas pada harga serta return saham batu bara.

Solvabilitas adalah rasio yang mampu mengukur sampai berapa jauh perusahaan dibiayai oleh dana pinjaman. Solvabilitas diproksikan dengan Debt to Equity Ratio (DER). Debt to Equity Ratio merupakan rasio yang menggambarkan seberapa besar proporsi dari modal yang dimiliki dapat menutupi hutang-hutang kepada pihak luar (Ehrhardt \& Brigham, 2010:95). Tingkat rasio yang semakin tinggi mengindikasikan semakin rendahnya pendanaan perusahaan yang tersedia dari pemegang saham. Solvabilitas yang diproksikan dengan DER dianggap perlu menjadi variabel penelitian ini karena karakteristik perusahaan batu bara yang menggunakan hutang untuk modal usahanya. DER mampu menunjukkan perbandingan besaran hutang terhadap ekuitas perusahaan batu bara sehingga mampu menunjukkan risiko perusahaan batu bara tersebut. Besar kecilnya DER menunjukkan sinyal baik dan buruk kepada investor terhadap sumber modal perusahaan serta risiko perusahaan tersebut, sehingga akan mempengaruhi permintaan saham batu bara dan harga serta return saham batu bara.

Penelitian yang dilakukan oleh Arista \& Astohar (2012) menyatakan DER tidak mempunyai pengaruh terhadap return saham. Hermawan (2012), Rafique (2012), Susilawati (2013), Haque \& Faruquee (2013), Astutik et al. (2015), Abditama \& Damayanti (2015) dan Hendro \& Tri (2016), Astuty (2017) menyatakan DER memiliki hubungan negatif yang signifikan terhadap return saham. Murniatti (2016) menyatakan DER berpengaruh positif signifikan terhadap return saham. 
Berdasarkan latar belakang permasalahan dan hasil penelitian sebelumnya ditemukan perbedaan pengaruh faktor kurs, Gross Domestic Product dan solvabilitas terhadap return saham, maka diperlukan penelitian kembali untuk memperjelas temuan penelitian sebelumnya. Maka rumusan masalah dalam penelitian ini adalah: 1) Apakah kurs berpengaruh terhadap return saham investor pada perusahaan pertambangan sub sektor batu bara di BEI periode 2014-2017. 2) Apakah GDP berpengaruh terhadap return saham investor pada perusahaan pertambangan sub sektor batu bara di BEI periode 2014-2017. 3) Apakah solvabilitas berpengaruh terhadap return saham investor pada perusahaan pertambangan sub sektor batu bara di BEI periode 2014-2017.

Penelitian ini diharapkan dapat menambah pengetahuan, wawasan, informasi serta sebagai referensi untuk penelitian selanjutnya mengenai kurs, Gross Domestic Product dan solvabilitas terhadap return saham investor di saham batu bara. Hasil penelitian ini juga diharapkan dapat memberikan informasi bagi para investor dalam melakukan investasi di pasar modal.

Investasi pada hakikatnya merupakan penempatan dana pada saat ini dengan harapan untuk memperoleh keuntungan di masa mendatang. Sejalan dengan Jones (2014:3) yang menyatakan bahwa investasi adalah suatu komitmen keuangan pada satu atau beberapa aset yang akan dipegang untuk suatu kurun waktu tertentu dimasa yang akan datang.

Seseorang baik yang terlibat dalam bisnis maupun tidak secara individual akan mengeluarkan sejumlah dana pada masa sekarang dan memiliki harapan untuk mendapatkan pengembalian dalam jumlah yang lebih banyak pada masa yang akan datang. Investasi merupakan sebuah keputusan yang dibuat oleh individu atas sumber daya atau sejumlah dana yang dilakukan pada masa sekarang dengan harapan akan mendapatkan sejumlah keuntungan di masa yang akan datang (Tandellin, 2010:324)

Jones (2014:3) menyebutkan investasi mencakup suatu kegiatan yang luas, hal ini lebih mengarah pada simpanan dalam bentuk fisik seperti emas atau bangunan, maupun berbentuk sertifikat, bonds, common stock, atau mutual funds. Investasi dapat pula berarti beberapa aset dokumen lainnya seperti warrants, puts and calls, future contracts, dan convertible securities.

Menurut Jones (2014:389)analisis fundamental merupakan analisis yang digunakan untuk mencoba memprediksi harga saham di masa depan dengan memperkirakan nilai dari faktor-faktor fundamental yang dapat mempengaruhi harga saham di masa depan dengan menghubungkan variabel-variabel tersebut untuk mendapatkan jumlah taksiran harga saham. Model tersebut disebut juga sebagai share price forecasting model.

Return saham adalah tingkat keuntungan yang dinikmati oleh investor atas suatu investasi yang dilakukannya. Terdapat dua jenis return yaitu return realisasi yang merupakan return yang terjadi atau disebut juga sebagai return sesungguhnya dan return ekspektasi yang merupakan return yang diharapkan oleh investor.

Menghitung return saham atau total return terdiri dari capital gain (loss) dan yield. Capital gain (loss) adalah jumlah selisih antara nilai pembelian saham dengan nilai penjualan saham. Capital gain merupakan jumlah selisih yang terdapat antara harga penjualan saham lebih besar dengan harga belinya. Sebaliknya jika jumlah 
selisih antara harga jual saham lebih kecil dari harga belinya maka disebut dengan capital loss (Horne \& Wachowicz, 2013:98).

Yield (dividen) adalah laba bersih yang dibagikan oleh badan usaha kepada pemegang saham dan telah disepakati bersama pada rapat umum pemegang saham. Besar kecilnya proporsi laba yang didapatkan oleh badan usaha serta kebijakan pembagian deviden yang telah ditentukan akan mempengaruhi jumlah deviden yang dibagikan.

Kurs adalah tingkat dari nilai uang domestik yang dikonvesikan ke nilai mata uang asing (Bodie et al., 2014:175). Kurs merupakan catatan harga pasar mata uang asing ke dalam mata uang domestik begitu pula sebaliknya. Pemerintah Indonesia berperan penting dalam menentukan kurs agar tercapai situasi yang kondusif di dalam dunia usaha. Terutama kurs rupiah terhadap dollar yang sangat mempengaruhi arus barang dan jasa serta arus modal masuk dan keluar di Indonesia.

Gross Domestic Product (GDP) merupakan total dari ukuran produksi barang dan jasa di suatu negara Tandellin (2010:342). GDP adalah jumlah nilai produk oleh unit-unit produksi pada lingkup wilayah sebuah negara selama satu tahun dan biasanya digunakan sebagai ukuran kesejahteraan ekonomi suatu negara. GDP digunakan sebagai ukuran kesejahteraan ekonomi suatu negara karena mencakup semua hal yang diproduksi oleh perekonomian dan yang dijual secara legal di pasar.

Terjadinya pertumbuhan GDP yang cukup siginifikan dan cepat dalam kurun waktu tertentu di sebuah negara mengindikasikan bahwa pertumbuhan ekonomi juga sedang terjadi di negara tersebut Tandellin (2010:342). Pertumbuhan ekonomi yang membaik menunjukkan meningkatnya daya beli masyarakat, hal ini merupakan kesempatan bagi perusahaan-perusahaan untuk meningkatkan penjualannya. Meningkatnya penjualan perusahaan, menunjukkan meningkatnya keuntungan perusahaan.

Solvabilitas adalah rasio yang mampu mengukur sampai berapa jauh perusahaan dibiayai oleh dana pinjaman. Solvabilitas diproksikan dengan Debt to Equity Ratio (DER). Debt to Equity Ratio adalah rasio yang menggambarkan seberapa besar proporsi dari modal yang dimiliki dapat menutupi hutang-hutang kepada pihak luar (Ehrhardt \& Brigham, 2010:95). Tingkat rasio yang semakin tinggi mengindikasikan semakin rendahnya pendanaan perusahaan yang tersedia dari pemegang saham.

Berdasarkan latar belakang yang telah diuraikan, maka rumusan masalah dalam penelitian ini adalah: 1) Apakah kurs berpengaruh terhadap return saham investor pada perusahaan pertambangan sub sektor batu bara di BEI periode 20142017? 2) Apakah GDP berpengaruh terhadap return saham investor pada perusahaan pertambangan sub sektor batu bara di BEI periode 2014-2017? 3) Apakah solvabilitas berpengaruh terhadap return saham investor pada perusahaan pertambangan sub sektor batu bara di BEI periode 2014-2017?

Berdasarkan rumusan masalah di atas, maka tujuan penelitian dalam penelitian ini adalah sebagai berikut: 1) Untuk mengetahui signifikansi pengaruh kurs terhadap return saham investor pada perusahaan pertambangan sub sektor batu bara di BEI periode 2014-2017. 2) Untuk mengetahui signifikansi pengaruh GDP terhadap return saham investor pada perusahaan pertambangan sub sektor batu bara 
di BEI periode 2014-2017. 3) Untuk mengetahui signifikansi pengaruh solvabilitas terhadap return saham investor pada perusahaan pertambangan sub sektor batu bara di BEI periode 2014-2017.

Penelitian ini diharapkan dapat menambah pengetahuan, wawasan, informasi serta sebagai referensi untuk penelitian selanjutnya mengenai kurs, Gross Domestic Product dan solvabilitas terhadap return saham investor di saham batu bara. Hasil penelitian ini diharapkan dapat memberikan informasi bagi para investor dalam melakukan investasi di pasar modal.

Pihak bank sebagai kreditor akan menganggap bahwa semakin besar rasio ini maka akan semakin tidak menguntungkan dikarenakan beban yang ditanggung oleh perusahaan juga semakin besar yang berdampak pada ketidakmampuan perusahaan dalam melunasi hutang serta biaya bunga yang ditanggungnya. Bagi perusahaan justru semakin besar batas pengamanan bagi peminjam jika terjadi kerugian atau penyusutan aktiva. Rasio ini memberikan petunjuk umum tentang kelayakan dan risiko keuangan perusahaan.

Tingginya Debt to Equity Ratio menujukan tingginya penggunaan hutang sebagai sumber pendanaan perusahaan sehingga dapat memicu risiko yang cukup besar bagi perusahaan saat perusahaan tidak lagi memiliki kemampuan membayar kewajiban tersebut pada saat jatuh tempo, hal tersebut menyebabkan terganggunya kelanjutan operasi perusahaan karena akan dihadapkan oleh biaya bunga yang tinggi dan kemudian dalam jangka panjang laba perusahaan dapat mengalami penuruan.

Kurs adalah tingkat dari nilai uang domestik yang dikonvesikan ke nilai mata uang asing (Bodie et al., 2014:175). Kurs merupakan catatan harga pasar mata uang asing ke dalam mata uang domestik begitu pula sebaliknya. Pemerintah Indonesia berperan penting dalam menentukan kurs agar tercapai situasi yang kondusif di dalam dunia usaha.

Rupiah yang melemah terhadap Dolar meningkatkan permintaan ekspor akibat negara pengimpor memiliki purchasing power yang lebih besar karena bagi negara pengimpor harga batu bara domestik menjadi lebih murah. Meningkatnya kuantitas ekspor akibat depresiasi Rupiah terhadap Dolar meningkatkan profitabilitas perusahaan yang akan berimbas pada meningkatnya harga saham dan return saham. Begitu sebaliknya, jika Rupiah menguat terhadap Dolar, permintaan ekspor akan menurun sehingga profitabilitas perusahaan akan menurun, harga saham dan return saham juga menurun.

Penelitian yang dilakukan Hwang (2016), Octafia (2013), Ouma \& Muriu (2014) dan Saputra \& Dharmadiaksa (2016) menemukan hasil yang sama dimana kurs berpengaruh negatif dan signifikan terhadap return saham.

$\mathrm{H}_{1}$ : Kurs berpengaruh negatif dan signifikan terhadap return saham investor.

Gross Domestic Product (GDP) merupakan total dari ukuran produksi barang dan jasa di suatu negara Tandellin (2010:342). GDP terdiri atas konsumsi, investasi, pembelian pemerintah dan net ekspor suatu negara.

Meningkatnya GDP menunjukkan peningkatan laju pertumbuhan perekonomian negara. Meningkatnya laju pertumbuhan perekonomian negara menunjukkan meningkatknya besarnya purchasing power negara untuk melakukan aktifitas konsumsi, investasi dan pembelian pemerintah. 
Hal tersebut tentunya akan berdampak pada meningkatnya permintaan terhadap produk perusahaan, sehingga peningkatan laba perusahaan juga akan terjadi seiring dengan peningkatan tersebut pada akhirnya akan berakibat pada peningkatan harga saham yang secara otomatis akan meningkatkan return saham.

Begitu sebaliknya ketika GDP menurun, permintaan akan produk perusahaan akan menurun sehingga profitabilitas menurun dan berimbas pada harga dan return saham yang juga menurun.

Penelitian yang dilakukan oleh Haque \& Faruquee (2013) menyatakan bahwa GDP berpengaruh positif signifikan terhadap return saham.

$\mathrm{H}_{2}$ : Gross Domestic Product berpengaruh positif dan signifikan terhadap return saham investor.

Debt to Equity Ratio adalah rasio yang menggambarkan seberapa besar proporsi dari modal yang dimiliki dapat menutupi hutang-hutang kepada pihak luar (Ehrhardt \& Brigham, 2010:95). Tingkat rasio yang semakin tinggi mengindikasikan semakin rendahnya pendanaan perusahaan yang tersedia dari pemegang saham.

Tingkat hutang yang tinggi oleh perusahaan mengindikasikan bahwa perusahaan berkaitan dengan bunga dan beban yang ditanggungnya. Tingginya beban terhadap kreditur menunjukkan bahwa sumber investasi perusahaan dipengaruhi oleh pihak di luar perusahaan. Keadaan ini akan memberikan sinyal buruk kepada investor akibat perusahaan dinilai memiliki risiko yang besar.

Menurunnya permintaan akan saham tersebut akan menurunkan harga serta return saham. Begitu juga sebaliknya, jika DER rendah artinya sumber modal perusahaan tidak begitu banyak dipengaruhi pihak eksternal sehingga risiko investasi akan semakin kecil yang akan meningkatkan minat investor menanamkan modalnya di saham tersebut. Meningkatnya permintaan akan saham tersebut akan meningkatkan harga serta return saham.

Penelitian yang dilakukan oleh Hermawan (2012), Rafiqiue (2012), Susilawati (2013), Haque \& Faruquee (2013), Astutik et al. (2015), Abditama \& Damayanti (2015) dan Hendro \& Tri (2016), Astuty (2017) menyatakan DER memiliki hubungan negatif yang signifikan terhadap return saham.

$\mathrm{H}_{3}$ : Solvabilitas berpengaruh negatif dan signifikan terhadap return saham investor.

\section{METODE PENELITIAN}

Penelitian ini menggunakan pendekatan kuantitatif asosiatif. Pendekatan kuantitatif adalah metode penelitian yang digunakan untuk meneliti populasi atau sampel tertentu yang bertujuan untuk menguji hipotesis yang telah ditetapkan

Pendekatan asosiatif bersifat menghubungkan dua atau lebih fakta-fakta dan sifat-sifat obyek yang diteliti berdasarkan pada kerangka pemikiran tertentu dengan meneliti hubungan antar variabel independen dan variabel dependen. Penelitian ini dilakukan terhadap perusahaan pertambangan sub sektor batu bara yang terdaftar di Bursa Efek Indonesia (BEI) melalui situs resminya, www.idx.co.id.

Objek pada penelitian ini adalah kurs, Gross Domestic Product dan solvabilitas terhadap return saham perusahaan pertambangan sub sektor batu bara yang terdaftar di Bursa Efek Indonesia (BEI) pada tahun 2014-2017. 
Data kuantitatif yang digunakan meliputi data kurs, GDP dan laporan keuangan perusahaan pertambangan sub sektor batu bara yang terdaftar di Bursa Efek Indonesia (BEI) periode 2014 hingga 2017.

Data kualitatif yang digunakan dalam penelitian ini meliputi gambaran umum perusahaan pertambangan sub sektor batu bara yang terdaftar di Bursa Efek Indonesia (BEI) periode 2014 hingga 2017.

Sumber data yang digunakan dalam penelitian ini merupakan sumber sekunder berupa laporan keuangan dan profil perusahaan pertambangan sub sektor batu bara yang terdaftar di Bursa Efek Indonesia (BEI) selama periode 2014 hingga 2017 melalui website resmi BEI www.idx.co.id, data kurs melalui website resmi Bank Indonesia www.bi.go.id serta.data GDP melalui website resmi BPS www.bps.go.id.

Tabel 2.

Sampel Perusahaan Pertambangan Sub Sektor Batu Bara yang terdaftar di BEI

\begin{tabular}{ll}
\hline No. & \multicolumn{1}{c}{ Nama Perusahaan } \\
\hline 1 & PT. Adaro Energy Tbk. (ADRO) \\
2 & PT. Atlas Resources Tbk (ARII) \\
3 & PT. Baramulti Suksessarana Tbk. (BSSR) \\
4 & PT. Bumi Resources Tbk. (BUMI) \\
5 & PT. Bayan Resources Tbk. (BYAN) \\
6 & PT. Darma Henwa Tbk. (DEWA) \\
7 & PT. Delta Dunia Makmur Tbk. (DOID) \\
8 & PT. Golden Energy Mines Tbk.(GEMS) \\
9 & PT. Harum Energy Tbk. (HRUM) \\
10 & PT. Indo Tambangraya Megah Tbk. (ITMG) \\
11 & PT. Resource Alam Indonesia Tbk.(KKGI) \\
12 & PT. Samindo Resources Tbk. (MYOH) \\
13 & PT. Perdana Karya Perkasa Tbk. (PKPK) \\
14 & PT. Bukit Asam Tbk. (PTBA) \\
15 & PT. Petrosea Tbk. (PTRO) \\
16 & PT. Golden Eagle Energy Tbk. (SMMT) \\
17 & PT. Toba Bara Sejahtra Tbk. (TOBA) \\
Sumber: Data diolah (2018).
\end{tabular}

Populasi dalam penelitian ini adalah seluruh perusahaan pertambangan sub sektor batu bara yang terdaftar di Bursa Efek Indonesia (BEI) selama periode 2014 hingga 2017.

Perusahaan yang didapat yaitu sejumlah 17 perusahaan yang terdaftar di Bursa Efek Indonesia pada periode 2014 hingga 2017.

Pada peneltian ini teknik sampling yang digunakan adalah teknik sampel sampling jenuh, sehingga dalam hal ini sampel yang diambil yaitu seluruh populasi penelitian sebanyak 17 sampel.

Pada penelitian ini menggunakan pengumpulan data observasi non partisipan sebagai metode pengumpulan data yang berupa data laporan keuangan pada perusahaan pertambangan sub sektor batu bara yang terdaftar di Bursa Efek Indonesia (BEI) periode 2014-2017 dan dipublikasikan pada website 
www.idx.co.id, data kurs diakses melalui website resmi Bank Indonesia www.bi.go.id dan data GDP diakses melalui website resmi BPS www.bps.go.id.

Teknik analisis data menggunakan analisis statistik deskriptif dilanjutkan dengan melakukan uji asumsi klasik yang berupa normalitas untuk menguji apakah model regresi antara variabel dependen dengan variabel independen distribusi normal.

Uji autokorelasi digunakan untuk menguji jika terdapat korelasi atau kesalahan pengganggu pada periode penelitian dan sebelumnya dalam suatu model regresi linear. Uji multikolinearitas digunakan untuk menguji jika terdapat korelasi antar variabel independen pada model regresi.

Uji heteroskedastisitas untuk menguji jika terjadi ketidaksamaan varian dari residual satu pengamatan ke pengamatan yang lain dalam model regresi yang digunakan.

Analisis regresi digunakan untuk mengukur hubungan antar variabel serta untuk menunjukkan hubungan antar variabel tersebut yaitu variabel dependen dan variabel independen.

Perhitungan analisis data diawali dengan menghitung besarnya nilai dari masing-masing variabel dependen dan independen kemudian meregresikan variabel-variabel tersebut dengan model regresi linier berganda.

Penggunaan analisis regresi linier berganda bertujuan untuk mengetahui pengaruh yang terjadi antar variabel dengan menentukan nilai dari variabel penelitian yaitu harga saham sebagai variabel dependen untuk menaksir nilai-nilai yang berhubungan dengan likuiditas, solvabilitas, laba per lembar saham dan kurs sebagai variabel independen menggunakan rumus statistik sebagai berikut :

$$
\mathrm{Y}=\alpha+\beta 1 \mathrm{X} 1+\beta 2 \mathrm{X} 2+\beta 3 \mathrm{NX} 3+\mathrm{ei}
$$

$$
\begin{array}{ll}
\text { Keterangan: } & \\
\mathrm{Y} & =\text { Harga saham } \\
\alpha & =\text { Konstanta } \\
\beta 1, \ldots, . ., \beta 4 & =\text { Koefisien regresi } \\
\mathrm{X} 1 & =\text { Kurs } \\
\mathrm{X} 2 & =\text { Gross Domestic Product } \\
\mathrm{X} 3 & =\text { Solvabilitas } \\
\text { ei } & =\text { Kesalahan residual (error) }
\end{array}
$$

Selanjutnya diakukan pengujian hipotesis dengan menggunakan uji regresi parsial (Uji t) yang bertujuan untuk membantu peneliti apakah dalam model regresi variabel independen secara parsial mempengaruhi variabel dependen.

Analisis koefisien determinasi $\left(\mathrm{R}^{2}\right)$ untuk mengukur seberapa jauh kemampuan model dalam menerangkan variasi variabel dependen

\section{HASIL DAN PEMBAHASAN}

Sebagian besar responden adalah laki-laki sebanyak 51 orang dengan presentase 91,07 persen, sedangkan sisanya adalah perempuan sebanyak 5 orang dengan persentase 8,92 Persen. Artinya sebagian besar karyawan PT. Ayu Sari 
Pertiwi mempekerjakan tenaga laki-laki. Hal ini dikarenakan sebagian besar karyawan dibidangnya diperlukan tenaga laki-laki.

Analisis deskriptif dilakukan untuk menggambarkan seluruh variabel dalam penelitian antara lain : kurs $\left(\mathrm{X}_{1}\right), G D P\left(\mathrm{X}_{2}\right)$, solvabilitas $\left(\mathrm{X}_{3}\right)$ dan return saham $(\mathrm{Y})$ yang ditunjukkan pada Tabel 3 .

Hasil statistik deskriptif yang ditunjukkan pada tabel 3, dapat terlihat bahwa nilai minimum return saham adalah sebesar $-0,9 \%$ dengan nilai maksimumnya yaitu sebesar $8,44 \%$.

Hal tersebut mengandung makna bahwa besarnya return saham pada sampel penelitian ini berkisar antara -0,9\% sampai 8,44\% dengan rata-rata sebesar 0,29397 pada standar deviasi sebesar 1,247017.

Nilai return saham tertinggi pada PT. Delta Dunia Makmur Tbk. tahun 2016 adalah sebesar $8,44 \%$ sedangkan nilai return saham terendah pada PT. Golden Eagle Energy Tbk. tahun 2015.

Tabel 3.

Hasil Statistik Deskriptif Sampel Penelitian

\begin{tabular}{lccccc}
\hline & N & Min & Max & Mean & Std. Deviation \\
\hline Return Saham & 68 & $-0,900$ & 8,440 & 0,29397 & 1,247017 \\
Kurs & 68 & 12,440 & 13,800 & 13,35191 & 0,473451 \\
GDP & 68 & 1,870 & 2,460 & 2,18206 & 0,247402 \\
Solvabilitas & 68 & $-9,870$ & 13,390 & 1,38456 & 2,755298 \\
Valid N & 68 & & & & \\
\hline
\end{tabular}

Sumber : Data Diolah, 2018.

Variabel kurs mempunyai nilai minimum yaitu Rp 12.440 dan nilai maksimumnya adalah sebesar Rp 13.800. Hal tersebut mengandung makna bahwa besarnya kurs pada sampel penelitian ini berkisar antara Rp 12.440 sampai dengan $\mathrm{Rp} 13.800$ dengan rata-rata sebesar Rp 13,35191 pada standar deviasi sebesar 0,473451 .

Nilai kurs tertinggi adalah pada tahun 2015 yaitu Rp 13.800 sedangkan nilai kurs terendah yaitu $\mathrm{Rp} 12.440$ adalah pada tahun 2014.

Variabel GDP mempunyai nilai minimum yaitu 1,870 dan nilai maksimumnya adalah sebesar 2,460. Hal tersebut mengandung makna bahwa besarnya $G D P$ pada sampel penelitian ini berkisar antara 1,870 sampai dengan 2,460 dengan rata-rata sebesar 2,18206 pada standar deviasi sebesar 0,247402.

Nilai GDP tertinggi adalah pada tahun 2014 yaitu 2,460 sedangkan nilai $G D P$ terendah yaitu 1,870 adalah pada tahun 2016 .

Variabel solvabilitas mempunyai nilai minimum yaitu $-9,870$ dan nilai maksimum adalah sebesar 13,390. Hal tersebut mengandung makna bahwa besarnya solvabilitas sampel penelitian ini berkisar antara $-9,870$ sampai dengan 13,390 dengan rata-rata sebesar 1,38456 pada standar deviasi sebesar 2,755298.

Nilai solvabilitas tertinggi pada PT. Bumi Resources Tbk. (BUMI) adalah pada tahun 2017 yaitu 13,390 sedangkan nilai solvabilitas terendah yaitu $-9,870$ pada PT. Bumi Resources Tbk. (BUMI) adalah pada tahun 2014. 
Tabel 4.

Hasil Uji Normalitas

\begin{tabular}{lll}
\hline & Unstandardized Residual & \\
\hline $\mathrm{N}$ & & 68 \\
Normal Parameters ${ }^{\mathrm{a}, \mathrm{b}}$ & Mean & $-0,0869089$ \\
& Std. Deviation & 76628055 \\
& Absolute & 0,113 \\
& Positif & 0,113 \\
& Negatif & $-0,065$ \\
Test Statistic & & 0,929 \\
Asymp. Sig. & & 0,354 \\
\hline Sumber : Data Diolah, 2018. & &
\end{tabular}

Berdasarkan Tabel 4. nilai asymp. sig sebesar 0,354 yang berarti nilainya lebih besar dari 0,05 hal tersebut mengandung makna bahwa data dalam penelitian ini telah berdistribusi normal.

Pengujian autokorelasi dilakukan dengan Uji Durbin Watson (DW-test). Pengujian dilakukan untuk mengetahui pengaruh yang terjadi pada data dari pengamatan sebelumnya dalam model regresi linier.

Jika suatu model regeresi mengandung gejala autokorelasi, maka prediksi yang dilakukan dengan model tersebut akan tidak baik atau dapat memberikan hasil produksi yang menyimpang.

Adapun hasil pengujian autokorelasi dalam penelitian ini disajikan dalam Tabel 5 sebagai berikut

Tabel 5.

Hasil Uji Autokorelasi (DW-test)

\begin{tabular}{llllll}
\hline Model & R & R Square & Adjusted R Square & $\begin{array}{c}\text { Std. Error of the } \\
\text { Estimate }\end{array}$ & $\begin{array}{c}\text { Durbin - } \\
\text { Watson }\end{array}$ \\
\hline 1 & $0,403^{\mathrm{a}}$ & 0,162 & 0,123 & 1,167706 & 1,772 \\
\hline
\end{tabular}

Sumber : Data Diolah, 2018.

Tabel 5. menunjukkan hasil uji autokorelasi yaitu nilai dw yang dihasilkan adalah sebesar 1,772. Berdasarkan jumlah $\mathrm{n}=68$ dan $\mathrm{k}=3$, pada tabel DurbinWatson sehingga didapatkan hasil nilai $\mathrm{d}_{\mathrm{L}}=1,5164$ dan $\mathrm{d}_{\mathrm{U}}=1,7001$ selain itu diperoeh juga nilai $4-\mathrm{d}_{\mathrm{U}}=2,2999$ berdasarkan hal tersebut dapat dirumuskan kriteria $\mathrm{d}_{\mathrm{U}}<\mathrm{d}_{\mathrm{w}}<4-\mathrm{d}_{\mathrm{U}}$ yaitu $(1,7001<1,772<2,2999)$. Hal tersebut mengandung makna bahawa kseluruhan data yang digunakan pada penelitian ini bebas dari autokorelasi.

Uji multikolinearitas bertujuan untuk menguji apakah di dalam model regresi ditemukan adanya korelasi antara variabel bebas.

Berdasarkan hasil uji multikolinearitas pada Tabel 6. dapat diketahui nilai korelasi variabel kurs dengan variabel solvabilitas adalah sebesar 0,120 $(<0,90)$, nilai korelasi variabel kurs dengan $G D P$ adalah sebesar $-0,564(<0,90)$, serta nilai variabel solvabilitas dan variabel $G D P$ adalah $-0,016(<0,90)$.

Nilai tolerance dan VIF dari variabel kurs sebesar 0,670 $(>0,1)$ dan 1,493 $(<10)$, GDP sebesar 0,679 $(>0,1)$ dan 1,472 $(<10)$, dan solvabilitas sebesar 0,982 yang diestimasi terhadap variabel independen. 
Berikut hasil dari pengujian heteroskedastisitas pada penelitian ini yang tersaji pada Tabel 7.

Tabel 6.

Hasil Uji Multikolinearitas

\begin{tabular}{|c|c|c|c|c|c|}
\hline \multirow[t]{2}{*}{ Model } & \multicolumn{2}{|c|}{$\begin{array}{l}\text { Unstandardized } \\
\text { Coefficients }\end{array}$} & \multirow{2}{*}{$\begin{array}{c}\text { Standardized } \\
\text { Coefficients } \\
\text { Beta }\end{array}$} & \multirow[t]{2}{*}{ Sig. } & \multirow[t]{2}{*}{$\begin{array}{l}\text { Hasil uji } \\
\text { Hipotesis }\end{array}$} \\
\hline & B & $\begin{array}{l}\text { Std. } \\
\text { Error }\end{array}$ & & & \\
\hline (Constant) & 15,122 & 5,909 & & 0,013 & \\
\hline Kurs & $-0,780$ & 0,368 & $-0,296$ & 0,038 & Diterima \\
\hline$G D P$ & $-2,090$ & 0,700 & $-0,415$ & 0,004 & Ditolak \\
\hline Solvabilitas & 0,106 & 0,052 & 0,234 & 0,047 & Ditolak \\
\hline Adjusted $\mathrm{R}^{2}$ & & & & & 0,142 \\
\hline
\end{tabular}

Sumber : Data Diolah, 2018.

Tabel 7.

Hasil Uji Heteroskedastisitas

\begin{tabular}{llccccc}
\hline \multicolumn{2}{c}{ Model } & Kurs & GDP & Solvabilitas & Tolerance & VIF \\
\hline Correlation & Kurs & 1,000 & $-0,564$ & 0,120 & 0,670 & 1,493 \\
& GDP & $-0,564$ & 1,000 & $-0,016$ & 0,679 & 1,472 \\
& Solvabilitas & 0,120 & $-0,016$ & 1,000 & 0,982 & 1,019 \\
\hline
\end{tabular}

Sumber : Data Diolah, 2018.

Tabel 7. menunjukkan hasil uji heteroskedastisitas, sehingga dapat diketahui besar nilai signifikansi dari variabel kurs adalah 0,253 $(>0,05)$, variabel GDP yaitu $0,053(>0,05)$ dan variabel solvabilitas yaitu $0,173(>0,05)$.

Nilai signifikansi dari masing-masing variabel independen terhadap variabel absolute residual berada diatas 0,05 sehingga kesimpulan yang didapatkan adalah tidak terdapat masalah heteroskedastisitas pada data yang digunakan dalam penelitian ini.

Penelitian ini menggunakan model analisis berupa analisis regresi linear berganda. Penggunaan model ini bertujuan untuk mengetahui pengaruh kurs $\left(\mathrm{X}_{1}\right)$, $G D P\left(\mathrm{X}_{2}\right)$ dan solvabilitas $\left(\mathrm{X}_{3}\right)$ terhadap return saham $(\mathrm{Y})$ pada perusahaan pertambangan sub sektor batu bara periode 2014-2017.

Hasil uji analisis regresi linier berganda pada Tabel 8. menunjukkan variabel kurs mempunyai nilai koefisien regresi yaitu $-0,780$. Nilai negatif pada variabel kurs mangandung makna bahwa terdapat hubungan yang berlawanan arah.

Meningkatnya nilai kurs sebesar satu Rupiah akan berdampak pada penurunan return saham sebesar $-0,780$ satuan dengan syarat variabel bebas lainnya konstan atau sama dengan nol.

Variabel GDP mempunyai nilai koefisien regresi yaitu $-2,090$. Nilai negatif pada variabel $G D P$ mangandung makna bahwa terdapat hubungan yang berlawanan arah. Meningkatnya nilai GDP sebesar satu Rupiah akan berdampak pada 
penurunan return saham sebesar -2,090 satuan dengan syarat variabel bebas lainnya konstan atau sama dengan nol.

Tabel 8.

Hasil Uji Regresi Berganda

\begin{tabular}{lccccc}
\hline Model & \multicolumn{2}{c}{$\begin{array}{c}\text { Unstandardized } \\
\text { Coefficients }\end{array}$} & $\begin{array}{c}\text { Standardized } \\
\text { Coefficients } \\
\text { Beta }\end{array}$ & T & Sig. \\
& B & Std. Error & Beta & \\
\hline (Constant) & $-0,293$ & 1,995 & & $-0,147$ & 0,884 \\
Kurs & 0,143 & 0,124 & 0,160 & 1,154 & 0,253 \\
GDP & $-0,466$ & 0,236 & $-0,271$ & $-1,975$ & 0,053 \\
Solvabilitas & 0,024 & 0,018 & 0,158 & 1,379 & 0,173 \\
\hline Sumber :
\end{tabular}

Sumber : Data Diolah, 2018.

Hasil analisis pada Tabel 8. dapat dibuat persamaan regresi linear berganda sebagai berikut:

$$
Y=15,122-0,780 X 1-2,090 X 2+0,1060 X 3 .
$$

Keterangan:

$\mathrm{Y}=$ Return Saham

$\mathrm{a}=$ Konstanta

b1, b2, b3 = Koefisien Regresi

$\mathrm{X} 1=$ Kurs

$\mathrm{X} 2=G D P$

$\mathrm{X} 3$ = Solvabilitas

Variabel solvabilitas mempuyai nilai koefisien regresi yaitu 0,106 . Nilai positif pada variabel solvabilitas mangandung makna bahwa terdapat hubungan yang searah.

Meningkatnya nilai solvabilitas sebesar satu persen akan berdampak pada kenaikan tingkat return saham sebesar 0,106 satuan dengan syarat variabel bebas lainnya konstan atau sama dengan nol.

Hasil analisis pada Tabel 8 menunjukkan nilai signifikansi uji t dari variabel kurs dengan nilai $p$-value yaitu 0,038 lebih kecil dari $\alpha=0,05$ dengan nilai koefisien regresi $-0,780$ yang mengandung makna bahwa nilai kurs berpengaruh negatif dan signifikan pada return saham.

Variabel GDP mempunyai nilai signifikansi uji t dengan nilai $p$-value yaitu 0,004 lebih kecil dari $\alpha=0,05$ dengan nilai koefisien regresi $-2,090$ yang mengandung makna bahwa GDP berpengaruh negatif dan signifikan pada return saham.

Variabel solvabilitas mempunyai nilai signifikansi uji t dengan nilai $p$-value yaitu 0,047 lebih kecil dari $\alpha=0,05$ dengan nilai koefisien regresi 0,106 yang mengandung makna bahwa bahwa solvabilitas berpengaruh positif dan signifikan pada return saham.

Nilai dari adjusted $\mathrm{R}^{2}$ pada penelitian ini yang terlihat pada Tabel 8 adalah sebesar 0,142 . Hal tersebut mengandung makna bahwa terdapat sebanyak $14,2 \%$ variasi perubahan return saham dapat dijelaskan oleh variabel kurs, GDP dan solvabilitas, sedangkan sisanya sebesar $85,8 \%$ dipengaruhi oleh variabel lain diluar 
dari model penelitian.

Hasil pengujian atas pengaruh kurs (X1) pada return saham (Y) berdasarkan analisis yang telah dilakukan menunjukkan bahwa kurs berpengaruh negatif dan signifikan pada return saham. Berdasarkan hal tersebut maka hipotesis $\mathrm{H}_{1}$ yakni kurs berpengaruh negatif dan signifikan terhadap return saham investor dapat diterima.

Kurs menunjukkan pengaruh negatif dan signifikan terhadap return saham, hasil ini sesuai dengan hipotesis yang diajukan sebelumnya. Rupiah yang melemah terhadap Dolar meningkatkan permintaan ekspor akibat negara pengimpor memiliki purchasing power yang lebih besar karena bagi negara pengimpor harga batu bara domestik menjadi lebih murah.

Meningkatnya kuantitas ekspor akibat depresiasi Rupiah terhadap Dolar meningkatkan profitabilitas perusahaan yang akan berimbas pada meningkatnya harga saham dan return saham. Begitu sebaliknya, jika Rupiah menguat terhadap Dolar, permintaan ekspor akan menurun sehingga profitabilitas perusahaan akan menurun yang berimbas pada harga saham dan return saham juga menurun.

Nilai tukar mata uang sangat berperan penting dalam membentuk hasil keuntungan bagi pihak perusahaan, oleh karena itu sangat penting untuk melakukan pengamatan terhadap nilai tukar mata uang setiap saat terjadinya transaksi. Hal tersebut dapat mempengaruhi tindakan investor yang akan lebih berhati-hati untuk mengambil keputusan membeli atau menjual saat terjadinya nilai tukar mata uang yang tidak stabil.

Hasil penelitian ini sejalan dengan penelitian yang dilakukan oleh Octafia (2013) dan Saputra \& Dharmadiaksa (2016) yang menyebutkan bahwa nilai tukar berpengaruh negatif dan signifikan terhadap return saham. Menolak hasil dari Kutty (2010), Mgammal (2012), Odoyo et al. (2014), Kisaka \& Mwasaru (2014), Widyastuti (2017).

Hasil pengujian atas pengaruh $G D P(\mathrm{X} 2)$ pada return saham $(\mathrm{Y})$ berdasarkan analisis yang telah dilakukan dapat diketahui bahwa GDP berpengaruh negatif dan signifikan pada return saham. Berdasarkan hal tersebut maka hipotesis $\mathrm{H}_{2}$ yakni $G D P$ berpengaruh positif pada return saham ditolak. GDP yang meningkat di suatu negara menunjukkan terjadinya peningkatan kesejahteraan masyartakat.

Peningkatan kesejahteraan masyarakat tidak selalu diikuti dengan aktifitas investasi di pasar modal melainkan aktifitas investasi di sektor lainnya seperti pasar uang.

Berdasarkan data Bank Indonesia, Dana Pihak Ketiga (DPK) perbankan nasional per Desember 2015 tumbuh 7,26\% menjadi 4.413 triliun dari sebelumnya 4.114 triliun pada Desember 2014. Pada Agustus 2017, menurut Otoritas Jasa Keuangan pertumbuhan DPK perbankan menanjak 9,59\% menjadi Rp5.052 triliun dibandingkan dengan periode sama pada tahun 2016.

Beralihnya keputusan investor untuk berinvestasi di pasar uang menyebabkan penurunan investasi di pasar modal sehingga harga saham menurun dan berimbas pada return saham yang juga menurun (Swaonline, 2017).

Hasil penelitian ini sejalan dengan penelitian yang dilakukan oleh Indraswari \& Suryantini (2013) dan Sinaga (2014) dalam penelitiannya menyatakan bahwa $G D P$ berpengaruh negatif dan signifikan terhadap return saham. Hasil penelitian 
ini bertolak belakang dengan penelitian yang dilakukan oleh Haque \& Faruquee (2013) menyatakan bahwa GDP berpengaruh positif signifikan terhadap return saham. Hasil pengujian atas pengaruh solvabilitas (X3) pada return saham (Y) berdasarkan analisis yang telah dilakukan dapat diketahui bahwa solvabilitas berpengaruh positif dan signifikan pada return saham. Berdasarkan hal tersebut maka hipotesis $\mathrm{H}_{3}$ yakni solvabilitas berpengaruh negatif dan signifikan pada return saham ditolak.

Perusahaan pertambangan merupakan industri yang syarat dengan resiko, terutama di tahap eksplorasi hingga kontruksi yang membutuhkan modal yang sangat besar. Pendanaan tersebut sangat bergantung pada pinjaman dari perbankan. Solvabilitas merupakan cerminan penggunaan hutang di dalam pendanaan aktivitas perusahaan. Solvabilitas yang tinggi mampu meningkatkan modal perusahaan untuk melakukan aktifitas produksinya.

Meningkatnya modal perusahaan akan meningkatkan Earning After Tax perusahaan, hal ini akan memberikan sinyal yang positif terhadap investor untuk menanamkan modalnya di perusahaan tersebut akibat profitabilitas perusahaan meningkat. Meningkatnya demand investor terhadap saham perusahaan akan meningkatkan harga saham tersebut, begitu juga return saham tersebut.

Hasil penelitian ini sejalan dengan penelitian yang dilakukan oleh Wingsih (2013) dan Murniatti (2016) menunjukkan hasil bahwa solvabilitas berpengaruh positif signifikan terhadap return saham. Penelitian ini menunjukkan hasil yang berbeda dengan penelitian yang dilakukan oleh Arista \& Astohar (2012) menyatakan solvabilitas tidak mempunyai pengaruh terhadap return saham.

Hermawan (2012), Rafique (2012), Susilawati (2013), Haque \& Faruquee (2013), Astutik et al. (2015), Abditama \& Damayanti (2015) dan Hendro \& Tri (2016), Astuty (2017) menyatakan solvabilitas memiliki hubungan negatif yang signifikan terhadap return saham.

\section{SIMPULAN}

Berdasarkan hasil analisis dan pembahasan yang telah diuraikan diatas, maka dapat disimpulkan bahwa : kurs berpengaruh negatif dan signifikan pada return saham. Rupiah yang melemah terhadap Dolar meningkatkan permintaan ekspor akibat negara pengimpor memiliki purchasing power yang lebih besar karena bagi negara pengimpor harga batu bara domestik menjadi lebih murah.

Meningkatnya kuantitas ekspor akibat depresiasi Rupiah terhadap Dolar dapat meningkatkan harga saham dan return saham. GDP berpengaruh negatif dan signifikan pada return saham. Peningkatan GDP dalam suatu negara mengindikasikan adanya peningkatan kesejahteraan masyarakat yang tidak selalu diikuti dengan aktifitas investasi di pasar modal melainkan aktifitas investasi di sektor lainnya seperti pasar uang. Beralihnya keputusan investor untuk berinvestasi di pasar uang menyebabkan penurunan investasi di pasar modal sehingga harga saham menurun dan berimbas pada return saham yang juga menurun Solvabilitas berpengaruh positif dan signifikan pada return saham.

Solvabilitas yang tinggi mampu meningkatkan earning after tax (EAT) perusahaan. Meningkatnya EAT perusahaan akan memberikan sinyal yang positif terhadap investor untuk menanamkan modalnya di perusahaan tersebut. 
Meningkatnya demand investor terhadap saham perusahaan akan meningkatkan harga saham, begitu juga return saham tersebut. Berdasarkan simpulan yang dipaparkan diatas, maka saran yang dapat diberikan antara lain : Perusahaan pertambangan sub sektor batu bara hendaknya memperhatikan faktor eksternal dan internal khususnya kurs, $G D P$ dan solvabilitas. Berdasarkan hasil penelitian, bahwa variabel kurs, GDP dan solvabilitas berpengaruh terhadap return saham. Nilai koefisien determinasi (Adjusted $\mathrm{R}^{2}$ ) yang rendah mengindikasikan agar peneliti selanjutnya untuk mencari lebih banyak variabel yang mempengaruhi return saham selain variabel yang telah digunakan pada peneliatian ini. Variabel bebas yang dapat digunakan untuk penelitian selanjutnya yaitu berupa inflasi dan suku bunga maupun likuiditas, manajemen asset, profitabilitas, penilaian pasar yang juga memiliki pengaruh terhadap retrun saham.

Peneliti selanjutnya dapat memperluas penelitian pada ruang lingkup yang serupa dengan penelitian ini dan menggunakan jenis perusahaan lainnya yang mengandung nilai dari variabel-variabel yang dibutuhkan dalam penelitian sehingga hasil dari penelitian tersebut dapat dijadikan acuan dalam melakukan penelitian yang lebih luas dan juga dapat menjadi sumber informasi untuk berbagai pihak yang membutuhkan baik dari perusahaan emiten, peneliti selanjutnya, maupun masyarakat umum.

\section{REFERENSI}

Abditama, H. I., \& Damayanti, S. M. (2015). the Influence of Company Performance Toward Stock Price of Pt . XL Axiata Tbk. Journal of Business and Management, 4(4), 510-521.

Arif, I. (2014). Batubara Indonesia. Jakarta: Gramedia Pustaka Utama.

Arista, \& Astohar. (2012). Analisis Faktor-faktor yang Mempengaruhi Return Saham (Kasus pada Perusahaan Manufaktur yang Go Public di BEI periode tahun 2005-2009). Jurnal Ilmu Manajemen Dan Akuntansi Terapan, 3(1), 115.

Astutik, E. D., Surachman, S., \& Djazuli, A. (2015). The effect of fundamental and technical variables on stock price (Study on manufacturing companies listed in Indonesia Stock Exchange). Journal of Economics, Business, and Accountancy, 17(3), 345-352. https://doi.org/10.14414/jebav.v17i3.356

Astuty, P. (2017). The Influence of Fundamental Factors and Systematic Risk to Stock Prices on Companies Listed in the Indonesian Stock Exchange. European Research Studies Journal, 20(4), 230-240.

Bodie, Z., Kane, A., \& Marcus, A. J. (2014). Investment. Buku Satu. Edisi Sembilan. Jakarta: Salemba Empat.

Ehrhardt, M., \& Brigham, E. F. (2010). Financial Management Theory and Practice (13th ed.). USA: South-Western Cengange Learning.

Haque, S., \& Faruquee, M. (2013). Impact of Fundamental Factors on Stock Price : 
A Case Based Approach on Pharmaceutical Companies Listed with Dhaka Stock Exchange. International Journal of Business and Management Invention, 2(9), 34-41.

Hendro, N., \& Tri, E. (2016). Analisis Pengaruh Nilai Tukar, Perdagangan, ROA, DER, dan Size Terhadap Harga Saham (Studi Kasus Pada Perusahaan yang terdaftar pada Indeks LQ45 Periode 2011-2014). Diponegoro Journal of Management, 5(1), 1-12.

Hermawan, D. A. (2012). Pengaruh Debt To Equity Ratio, Earning Per Share dan Profit Margin Terhadap Return Saham. Management Analysis Journal, 1(5), $1-17$.

Horne, J. C. Van, \& Wachowicz, J. M. J. (2013). Prinsip-Prinsip Manajemen Keuangan. Jakarta: Salemba Empat.

Hwang, J.-K. (2016). Cointegration And The Causality Between Stock Prices And Exchange Rates Of The Korean Economy. International Business \& Economics Research Journal (IBER), 3(4), 79-84. https://doi.org/10.19030/iber.v3i4.3684

Indraswari, A. A. A. R., \& Suryantini, N. P. S. (2013). Pengaruh Kondisi Ekonomi, Kondisi Pasar Modal dan Kinerja Keuangan terhadap Return Saham pada Perusahaan Automotive and Allied Products di BEI. E-Jurnal Manajemen Universitas Udayana, 2(12), 1597-1616.

Jones, P. C. (2014). Investments Principles and Concepts. Singapore: John Wiley and Sons.

Kisaka, S. E., \& Mwasaru, A. (2014). The Causal Relationship between Exchange Rates and Stock Prices in Kenya. Research Journal of Finance and Accounting, 3(7), 2222-2847.

Kutty, G. (2010). the Relationship Between Exchange Rates and Stock Prices : the Case of Mexico. North American Journal of Finance and Banking Research, $4(4), 1-12$.

Mgammal, M. (2012). The Effect of Inflation, Interest Rates and Exchange Rates on Stock Prices Comparative Study Among Two Gcc Countries. International Journal of Finance and Accounting, 1(6), 179-189.

Murniatti, S. (2016). Effect of Capital Structure, Company Size and Profitability on the Stock Price of Food and Beverage Companies Listed on the Indonesia Stock Exchange. Information Management and Business Review, 8(1), 23-29.

Octafia, S. M. (2013). Pengaruh Tigkat Suku Bunga SBI, Nilai Tukar dan Jumlah Uang Beredar terhadap Indeks Harga Saham Sektor Property dan Real Estate dengan Pendekatan Error Correction Model. Jurnal Manajemen, 2(11), 1-10.

Odoyo, F. S., Muasya, R., \& Kenneth, K. T. (2014). Effect of Foreign Exchange Rates on Price per Share. Business Administration and Education, 6(2), 34 
56.

Ouma, W. N., \& Muriu, P. (2014). The Impact of Macroeconomic Variables on Stock Market Return in Kenya. International Journal of Business and Commerce, 3(11), 1-31.

Rafique, M. (2012). Factors Affecting Dividen Payout: Evidence From Listed NonFinancial Firms of Karachi Stock Exchange. Business Management Dynamics, $1(1), 67-92$.

Saputra, A. A., \& Dharmadiaksa. (2016). Pengaruh Tingkat Suku Bunga, Nilai Tukar Rupiah, Leverage dan Profitabilitas pada Return Saham. E-Jurnal Akuntansi Universitas Udayana, 16(2), 1007-1033.

Sinaga, A. K. (2014). Pengaruh Faktor Fundamental dan Ekonomi Makro Terhadap Harga Saham. E-Jurnal Akuntansi Universitas Udayana, 1(1), 1412-1426.

Susilawati, C. D. K. (2013). Analisis Perbandingan Pengaruh Likuiditas, Solvabilitas, dan Profitabilitas Terhadap Harga Saham pada Perusahaan LQ 45. Jurnal Akuntansi, 4(2), 165-174.

Swaonline. (2017). Pertumbuhan Dana Pihak Ketiga Perbankan Nasional. Retrieved from https://swa.co.id/swa/trends/business-research/pertumbuhandana-pihak-ketiga-perbankan-nasional

Tandellin, E. (2010). Analisis Investasi dan Manajemen Portofolio. Yogyakarta: BPFE.

Widyastuti, M. (2017). Analysis of Effects of Inflation, Interest Rates, Rupiah Exchange Rate toward Composite Stock Price Index with the Gross Domestic Product as Moderation Variable in the Indonesia Stock Exchange. The International Journal of Business \&Management, 5(1), 35-42.

Wingsih, Y. (2013). Analisis Pengaruh Likuiditas, Profitabilitas, dan Solvabilitas terhadap Return Saham pada Perusahaan Pertambangan yang terdaftar di Bursa Efek Indonesia pada Tahun 2008 sampai 2012. Universitas Dian Nuswantoro. 